The Antiquaries fournal, 10o, 2020, pp 432-456 C The Society of Antiquaries of London, 2020. This is an Open Access article, distributed under the terms of the Creative Commons Attribution licence (http://creativecommons. $\mathrm{org} /$ licenses/by/4.0/), which permits unrestricted re-use, distribution, and reproduction in any medium, provided the original work is properly cited.

doi:I0.1017/S0003581520000256. First published online 05 August 2020

\title{
'SARSEN STONES IN WESSEX': A SOCIETY OF ANTIQUARIES PROJECT CONTEXTUALISED AND RENEWED
}

\begin{abstract}
Katy A Whitaker, FSA
Katy A Whitaker, 107 Pavenhill, Purton, Wiltshire SN5 4DB, UK. Email: k.a.whitaker@pgr.reading.ac.uk

This paper reviews the Society of Antiquaries' Evolution of the Landscape project, which started in 1974, and the project's Sarsen Stones in Wessex survey. The survey was an ambitious public archaeology undertaking, involving c 100 volunteers led by Fellows of the Society during the 1970s. Its aims, objectives and outcomes are described in this article. The survey's unique dataset, produced for the counties of Wiltshire, Hampshire and Dorset, has now been digitised. Drawing on the dataset, the paper situates the Evolution of the Landscape project in the context of later twentieth-century British archaeology. It demonstrates the importance not only of individual Fellows, but also contemporary movements in academic and development-led archaeology, to the direction of the Society's activities in this formative period for the discipline today, and shows how the Society's research was engaged with some of archaeology's most pressing cultural resource management issues.
\end{abstract}

Keywords: landscape archaeology; palimpsest; sarsen; GIS; Wessex; Neolithic; agriculture

\section{INTRODUCTION}

[It] might be useful to suggest a particular task which could be easily defined and probably achieved within a year. This was a search for the present and former location of sarsen stones. ${ }^{\mathrm{I}}$

Those Fellows of the Society of Antiquaries and their guests, who gathered on 23 February 1974 to inaugurate the 'Evolution of the Landscape' project, trod in the footsteps of eminent men including Mantell, Prestwich, Rupert Jones and Smith. ${ }^{2}$ In asking themselves 'what was the incidence of sarsen stone in prehistory?' (in particular, in the Neolithic), they situated themselves in a tradition of enquiry concerning the geological origins, distribution and uses of southern Britain's sarsen stones. Since the expansion of this research in the nineteenth century, aspects of geological, archaeological and ethnohistorical research into sarsen have often overlapped.

Sarsen is a silcrete sandstone (fig I). Discontinuously distributed across centralsouthern and eastern England as cobbles and boulders, sarsen was formed by the cementation of material in Tertiary sand and pebble beds by silica-rich groundwater or in

I. HEA, SOAo3/or, Evolution of the Landscape, Wessex Pilot Scheme News Sheet No. I.

2. Mantell I833; Prestwich I854; Smith I884; Rupert Jones I886. 


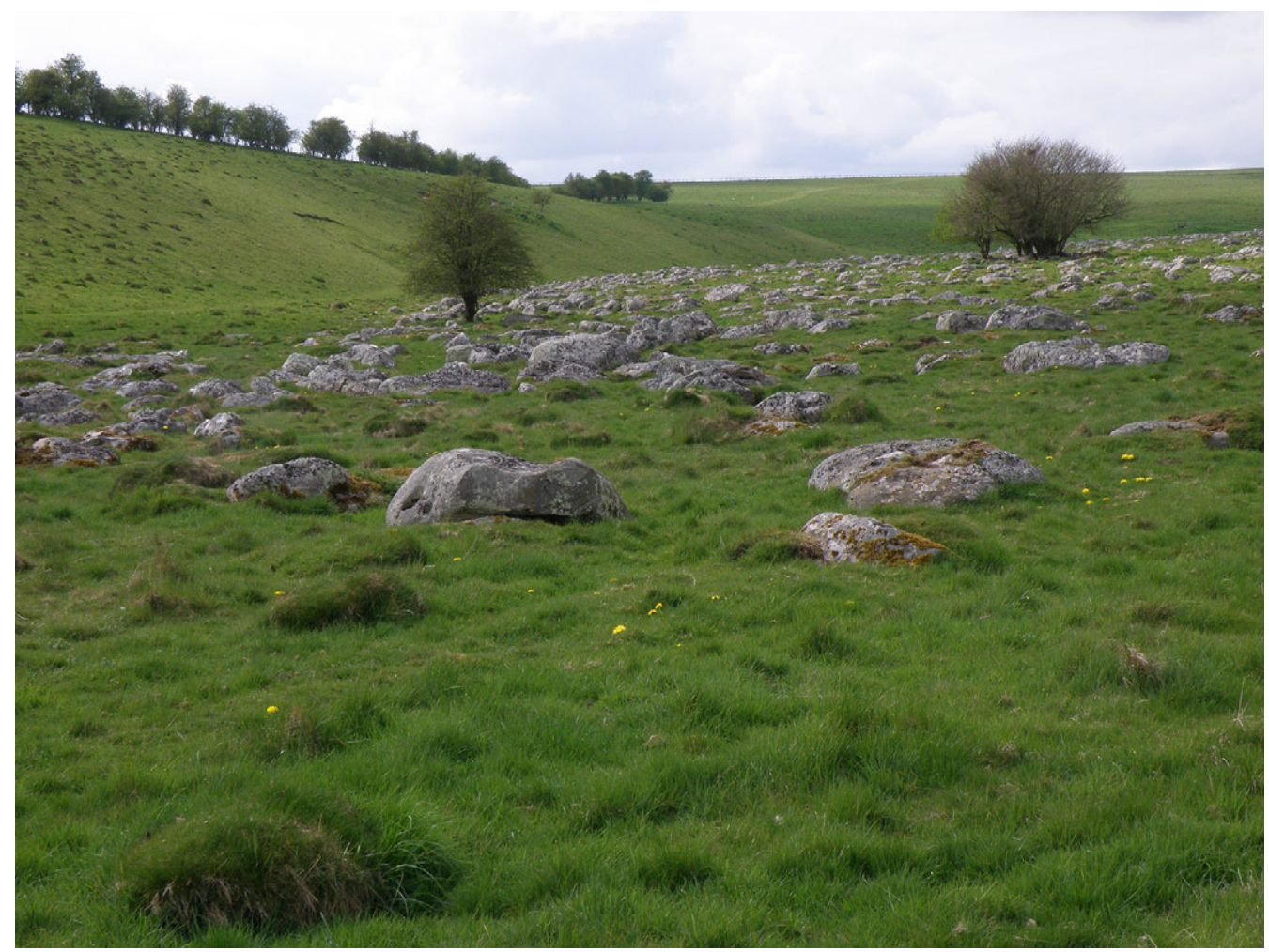

Fig I. The Valley of Stones, Marlborough Downs (Wiltshire) has one of England's few remaining large sarsen spreads. It is reputed to resemble the chalk upland before prehistoric and more recent clearance, commonly for agricultural purposes, removed stones from their natural positions. Despite the historical quarrying industry, there are estimated to be more than I0,000 sarsens lying in this dry chalk coombe (Small et al 1970). Photograph: the author.

drainage-line or pan/lacustrine settings. Whilst the processes of silica deposition in the host sediments were varied and occurred at different times, indurate sarsen stones are accessible on the present-day land surface (for example, in south-west Dorset) or buried in superficial deposits (such as over south Buckinghamshire's Chiltern Hills). ${ }^{3}$ Best known for its use in megalithic structures from Wiltshire to Kent, sarsen nevertheless can be seen in buildings of varying date, purpose and status (fig 2 ) across its distribution.

Since the Evolution of the Landscape project's sarsen survey in the I970s, archaeologists have largely been concerned with megalithic monuments built with this type of stone. There has been limited focus on the sarsen material itself, with some exceptions led most notably by researchers working in and around Avebury (Wiltshire). ${ }^{4}$ Contributing at a regional scale to an understanding of sarsen distribution in relation to prehistoric archaeology, the potential of the 'Sarsen Stones in Wessex' survey was never fully met by its

3. Small et al 1970; Summerfield and Goudie I980; Ullyot et al 2004; Nash and McLaren 2007; Ullyot and Nash 2016.

4. See in particular Gillings and Pollard 1999, 2004 and 2016a; Gillings et al 2008; Pollard and Gillings 2009, 2010. 


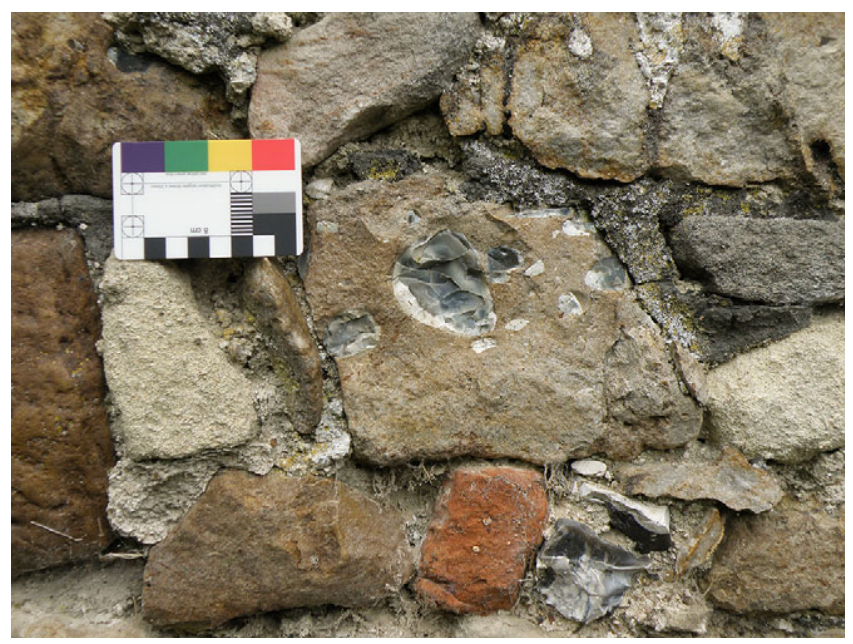

Fig 2. Sarsen in the walls of St Peter's church, Broad Hinton (Wiltshire), demonstrates the variability both of its use - here as rubble walling rather than cut blocks - and its lithology, with flint pebble clasts amongst the cemented sand in some pieces. Photograph: the author.

instigators. This is largely because of problems with its analogue dataset, and also in part due to deficiencies of the Evolution of the Landscape project's theoretical framework, which are discussed below.

This paper contextualises the Sarsen Stones in Wessex survey. It identifies contemporary conceptualisations of landscape as the main influence on the project's treatment of sarsen stone, strongly directed by practitioners of the British field archaeology tradition whose professional interests lay in the project's study area. The Evolution project's Sarsen survey epitomises the development of landscape archaeology in Britain after the Second World War. Whilst the survey's outputs were limited and now are physically compromised, a newly digitised dataset means that the project can play a part in answering recent calls to make a more effective exploration of past sarsen-scapes. ${ }^{5}$

\section{THE ‘EVOLUTION OF THE LANDSCAPE' PROJECT}

This project was one of two schemes introduced by Fellows $\mathrm{H}$ Collin Bowen and Barry Cunliffe in 1973, following suggestions that the Society become proactive in research ${ }^{6}$ (the other, the proposed archaeological investigation of churches, was prompted by threats to the Church of England estate from redundancy following the I968 Pastoral Measure). The Evolution project aimed to evaluate prehistoric population size and socio-economic organisation by researching changing land use. Like the churches proposal, it was also driven by perceived threats to the archaeological resource, which had already led to the creation of Rescue (The British Archaeological Trust) in I97I. Both proposals responded

6. Barry Cunliffe, pers comm, 26 Feb 2018. 
to the Society's need for an overarching research framework to direct the allocation of its funds to the right grant applications, given these challenges. ${ }^{7}$

The idea of the first human-made landscape was at the heart of the preparations. The purpose of the Evolution project as first proposed was 'to investigate the origins of the first organised landscape in Britain' - in particular, 'the lowest layer in this palimpsest, disclosing the period and the manner in which man first imposed a visible order on his countryside' ${ }^{8}$ As the idea developed during I972, with additional input from John Coles, the emphasis fell on 'the emerging possibility of recovering the earliest patterns of regular land allotment'. ${ }^{9}$ Throughout, the emphasis was on a project that would apply geographical and archaeological precepts to 'break away from the single site and single period approach' ${ }^{\circ}{ }^{\circ}$

The promoters of the Evolution project had already identified the Somerset Levels and Wessex as possible study areas. Wessex was suggested because of its extensive, wellpreserved, archaeological evidence for prehistoric land use, including earthwork field systems with stratigraphic relationships. ${ }^{\text {II }}$ By the time the extended proposal was written, the overarching aim had become an understanding of 'the size and disposition of the population and the nature of its economic and social organization. In this way, the dynamic processes at work within society may begin to be better appreciated.' Research already underway by, amongst others, local societies, university departments and government agencies, could support the essentially low-budget, collaborative approach espoused by the project's proposers, who called for a working party to be convened. Before a meeting was held, the project had been re-named from 'The Organisation of the Landscape' to 'The Evolution of the Landscape', ${ }^{\mathrm{I} 2}$ prefiguring Christopher Taylor's vision for research to illuminate change over deep time. ${ }^{\mathrm{I} 3}$

Collin Bowen then made a separate project proposal to his associates Richard Atkinson, Desmond Bonney, Richard Bradley, Geoffrey Kellaway and Isobel Smith. He proposed recording all the sarsen stones, whether extant or lost, in Hampshire, Wiltshire and Dorset, 'in order that archaeologists can assess the problems of clearance and the range of utilisation in geographical and functional terms from the earliest times' ${ }^{\text {I4 }}$

By the time of the inaugural 'Evolution of the Landscape, Wessex Pilot Project' meeting, held on 23 February 1974 with about forty invited attendees (unfortunately un-named in the minutes), two distinct methodologies had been identified. Cunliffe presented on the first: an intensive study of a small area of landscape, which he illustrated with reference to work already underway around Danebury. Bowen advocated surveying a far larger area for one class of data, proposing a sarsen stone study. The meeting concluded that both were of interest: the Danebury project would receive financial support; the sarsen survey would commence, using a pre-prepared information sheet and record-card. ${ }^{15}$

7. Bowen and Cunliffe 1973 .

8. SAL, MS $953 / \mathrm{I} / \mathrm{I}$, Proposal for a scheme to investigate the origin of the first organised landscape in Britain.

9. SAL, MS $953 / \mathrm{I} / \mathrm{I}$, Proposal for sponsorship of a scheme of research by the Society of Antiquaries of London.

Io. SAL, MS $953 / \mathrm{I} / \mathrm{I}$, The Organization of the Landscape - The Creation of the Project

II. Bowen and Cunliffe I973, 9.

I2. SAL, MS953/I/I, letter written by F H Thompson dated 9 Aug 1972.

I3. Taylor I974, I5I.

I4. HEA, SOAo3/I8, memorandum written by Collin Bowen dated 20 Dec I973.

I5. HEA, SOAo3/or, Evolution of the Landscape, Wessex Pilot Scheme News Sheet No. I. 
Volunteers led by Collin Bowen and Isobel Smith carried out the sarsen survey between I974 and 1976, outlined below. The results were published in The Antiquaries fournal in I977. Looking like an interim report, that paper was, in fact, the survey directors' only intended written output. Cunliffe's work at Danebury expanded into the 'Danebury Environs Project'. ${ }^{16}$ The aspiration of the Evolution of the Landscape project to be the focal point for ongoing research into the transformation of the countryside from wilderness to an organised and divided agricultural landscape was, however, not realised. John Evans' 'Wessex Linear Ditches' fieldwork ${ }^{17}$ and John Bailey's 'Parish Boundaries' project in Dorset $^{18}$ were supported financially by the Society of Antiquaries under the Evolution aegis, as was Martin Bell's 'Dry Valley' project. ${ }^{19}$ But Collin Bowen withdrew from further involvement in late 1978 in anticipation of his retirement. ${ }^{20}$

\section{THE 'SARSEN STONES IN WESSEX' SURVEY}

\section{Aims and objectives}

Intended to be the pilot scheme of the Evolution project, Collin Bowen proposed that a sarsen survey 'could be done by dividing the area between individuals and groups who would undertake to look everywhere within their individual pieces of jig-saw'. He advocated a project engaging volunteers, because they could complete work that for one person might take ' 24 man years'. ${ }^{2 I}$ Three project aims were articulated: to establish the former incidence of sarsen stone in the study area; to describe how sarsens had been dealt with (as a useful mineral resource or as impediments to land use); and to understand the effect of sarsen stones on underlying chalk bedrock.

The methodology was outlined in the project's 'Information Sheet No. I'. Volunteer participants would make a thorough search of Wiltshire, Dorset and Hampshire, annotating I:25,000-scale Ordnance Survey maps with the positions of sarsen stones. They were to record details of each stone or group of stones on pro-forma sheets called 'Tally Cards' (fig 3). At the end of the project the maps and sheets would be archived and a collated list of all the stones published. Certain sarsens would be excavated to investigate their relationship with bedrock, aiming to shed light, as Bowen put it, on 'the hollows that occasionally puzzle excavators'. ${ }^{22}$ Finally, a paper was to be published drawing the project's conclusions. The initial results were reviewed in May 1975. At that time, fieldwork in Dorset was 'substantially complete'23 and continuing in Hampshire and Wiltshire. By I977 it was almost finished, with acknowledged gaps in north-east Hampshire and in the militarily restricted Salisbury Plain Training Area.

The project leaders had, or came to develop, additional objectives not mentioned in either 'Information Sheet No. I' as circulated to the volunteers in I974, or in the final

I6. Cunliffe 2000.

I7. SAL, MS953/I/I, report written by John Evans dated 29 Nov 1977.

I8. SAL, MS953/I/I, letters written by John Bailey dated 20 Mar 1978, 29 Oct I98I and I I Apr I983.

I9. Bell I983.

20. SAL, MS953/I/I, letter written by Collin Bowen dated 6 Dec I 978.

2I. HEA, SOAo3/or, Evolution of the Landscape, Wessex Pilot Scheme News Sheet No. I.

22. HEA, SOAo3/o3, Sarsen Symposium, Evolution of the Landscape Project News Sheet No. 2.

23. Bowen and Smith 1977, I85. 


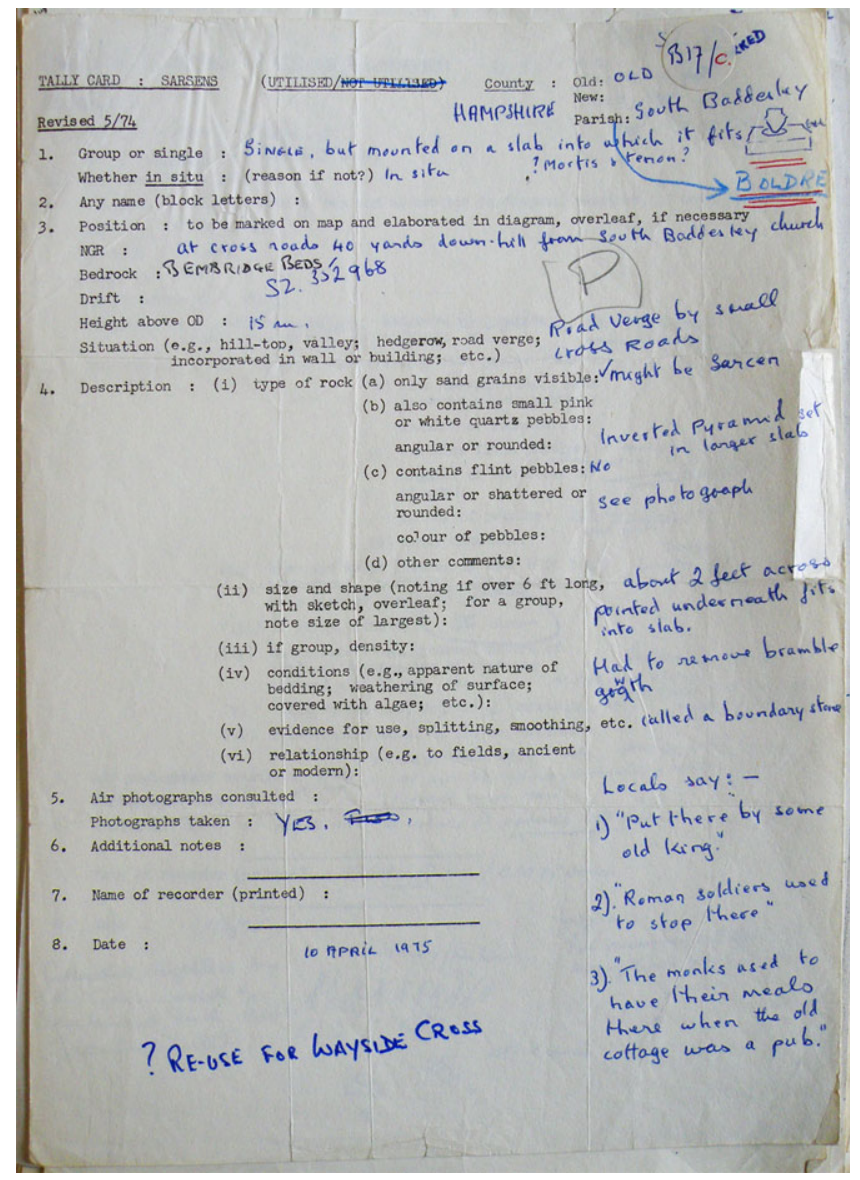

Fig 3. The Sarsen Stones in Wessex Tally Card for a possible sarsen stone recorded by a volunteer in Boldre (Hampshire), showing the information required by the project. Following the completion of the record, at least five additional notes were made, perhaps at different times and likely by different people, in pencils, black biro, red ink and blue felt-tip pen. SAL, MS953/3/2/I/BI7c.

Reproduced with the permission of the Society of Antiquaries of London. Photograph: the author.

published paper: Bowen had also wanted to identify owners, in order to persuade them of the importance of preserving the stones; to list sarsens on bedrock geology other than chalk; and to note sarsens incorporated into structures outside the generally recognised sarsen locales. ${ }^{24}$ By Io May 1975, when a progress meeting called the 'Sarsen Symposium' was held at Burlington House, Bowen was hopeful that the Wessex project archive would form the nucleus of a national sarsen record. ${ }^{25}$ Bowen's manuscript notes recording discussions with Isobel Smith show that they talked about: ${ }^{26}$ experimenting with sarsen stone dressing; investigating sarsen's 'case-hardening' effect; ${ }^{27}$ and using excavation

24. HEA, SOAo3/18, memorandum written by Collin Bowen dated 20 Dec 1973.

25. HEA, SOAo3/o3, Sarsen Symposium, Evolution of the Landscape Project News Sheet No. 2. 26. HEA, SOAo3/16, Sarsens. Notes.

27. See Summerfield and Goudie I980, 75. 
to find out whether or not sarsens occur naturally in mounds and as upright stones, and to investigate a standing stone. None of these wishes came to fruition, other than in minor ways; for example, the Wiltshire component of the survey includes records of sarsens on south-east Swindon's Greensand.

\section{Outcomes}

If considering solely the three main published aims and the field survey carried out by volunteers, the Sarsen survey was successful. The project mapped the presence of sarsen across the three counties, and a large dataset was gathered comprising nearly 900 records. As well as these field survey results, the dataset included a notable collection of published and unpublished references in its Tally Cards, especially for Dorset and Wiltshire, although little reference was made to commentaries on sarsen stone in the relevant British Geological Survey memoirs. If not the absolute former incidence of the stone in a geological sense, the project at least showed the range of sarsen's twentieth-century distribution in three counties in both 'natural' and anthropogenic contexts, hinting at the earlier availability of sarsen as a mineral resource. The project's valuable excavations at two sarsens on the Marlborough Downs demonstrated that one boulder lay directly on the Chalk bedrock, whilst the second, nearby, rested on a thin clay lens over the chalk. ${ }^{28}$ A hoped-for comparison with sarsens excavated from Clay-with-flints and sarsens in an uncertainly-prehistoric setting ${ }^{29}$ did not go ahead.

The concluding publication was co-authored by the project's leading investigators, Collin Bowen and Isobel Smith. Whilst it came out before the very last of the survey was assembled, the synthesis was felt to offer 'a consistent statement of distribution'30 of the stone. Bowen and Smith concluded that sarsens had hardly been an obstacle to farming, having been densest in areas of Wiltshire and Dorset that were also densely occupied in prehistory. ${ }^{3 \mathrm{I}}$ Within the paper, the principal products included three black and white distribution maps. ${ }^{32}$ Despite a note from Paul Ashbee to Collin Bowen mentioning that Ashbee had a 'rough list' 33 of sarsens in Kent, none appear in the published southern England general distribution map. Neither is the presence of sarsen in counties including Berkshire, Surrey or Sussex indicated. Some distribution data provided by Andrew Goudie for eastern England were included. The figures also indicate a few records in Surrey, just over the Hampshire county boundary, whilst records collected by volunteer Peter Gallup after publication could not be included.

The dataset had some significant gaps, including the absence of records of sarsen-built features and natural sarsen spreads from a substantial proportion of map-sheets SUI6 and SUI7, the area immediately to the south and east of Avebury (Wiltshire). Sarsen there had been deemed to be too prolific for enumeration; 34 it is unclear how points in these unrecorded areas around Avebury were created for the published Wiltshire distribution map. The West Kennet Long Barrow; the stone settings of Avebury henge; the Overton Down

28. Bowen and Smith 1977, I94-5.

29. HEA, SOA03/16, Sarsens. Notes.

30. Bowen and Smith 1977, I86.

3I. Ibid, I95.

32. Ibid, I 88 fig I, I90 fig 2 and I 92 fig 3.

33. HEA, SOA03/48, letter written by Paul Ashbee dated I4 Oct I975.

34. SAL, MS953/4/I/SUI6, MS953/4/I/SUI7. 
Table 1. The different record formats used by volunteers in the Sarsen Stones in Wessex survey, with frequency by type and county. The total of 879 includes seven records of areas unsuccessfully searched for sarsens.

\begin{tabular}{lccccccc}
\hline COUNTY & $\begin{array}{c}\text { Tally Card: } \\
\text { sarsens }\end{array}$ & $\begin{array}{c}\text { Tally Card } \\
\text { Revised } 5 / 74\end{array}$ & $\begin{array}{c}\text { Tally Card: } \\
\text { sarsen JB }\end{array}$ & Handmade & Postcards & $\begin{array}{c}\text { Other } \\
\text { format }\end{array}$ & TOTAL \\
\hline Hampshire & 6 & 300 & 0 & 5 & 0 & 0 & $\mathbf{3 I I}$ \\
Dorset & $4 \mathrm{I}$ & 5 & 86 & 0 & 0 & I & $\mathbf{1 3 3}$ \\
Wiltshire & $\mathrm{I}$ & 26 & 0 & 62 & $\mathbf{1 3 2}$ & $\mathbf{2 I} 4$ & $\mathbf{4 3 5}$ \\
TOTAL & $\mathbf{4 8}$ & $\mathbf{3 3 I}$ & $\mathbf{8 6}$ & $\mathbf{6 7}$ & $\mathbf{1 3 2}$ & $\mathbf{2 1 5}$ & $\mathbf{8 7 9}$ \\
$\quad$ RECORDS & & & & & & & \\
\hline
\end{tabular}

axe polissoir and the cup-marked sarsen; the 'sarsen villages'; sarsen spreads in Clatford, Lockeridge, Piggledene: none were recorded.

The analysis was beset by a number of issues. Differences between the survey's conduct in the three counties were conceded; for example, the Dorset results were felt to include a detailed record of 'natural' sarsen distribution, whilst Hampshire records focused on utilised sarsens in anthropogenic contexts. ${ }^{35}$ This variability, resulting in part from inconsistencies in how records were made in each county and also volunteers' different interpretations of the Tally Card pro-forma, is apparent in the archived datasets.

There were three versions of the project's Tally Card recording forms. These included the original, 'Tally Card: sarsen' (forty-eight records), a later iteration 'Tally Card Revised 5/74' (33I records) and an expanded version made by John Bailey and used only in Dorset, 'Tally Card: sarsen JB' (eighty-six records). In total they account for 53 per cent of all records (table I). The forms included eight broad categories of data. Each category comprised a number of more-or-less discrete items of information, recorded by the volunteers in a semi-structured way without controlled language or mandatory fields. Information could be written anywhere on the sheet, with sketches and additional information on the reverse (see fig 3). Most Tally Cards were not duplicated from a master document, but typed out when fresh sheets were needed. There are therefore some inconsistencies from sheet to sheet, with categories and questions missed out or placed in a slightly different location on the page. Occasionally a volunteer noticed a missing question and wrote it in themselves; at other times, not. Remaining records were made on handmade versions (sixty-seven records), postcards ( 132 records) and other formats (2 I5 records) (see table I).

All bar five of the 3II Hampshire and one of the 133 Dorset records used variants of the project's Tally Cards. In contrast, the bulk of the 435 records for Wiltshire were made on small postcards and typescript notes (see table I). Capturing very few of the Tally Card data categories, they include many bibliographic references for both extant and long-lost stones. Isobel Smith had made an extensive literature search for the county (30 per cent of Wiltshire records), which neither the Hampshire co-ordinator, Peter Gallup, nor the Dorset co-ordinator, John Bailey, attempted. Only 5 per cent of Hampshire and 7 per cent of Dorset records came from published sources, compared with 77 per cent and 86 per cent respectively from visits (table 2). As well as the locations of sarsens in natural and anthropogenic contexts, the volunteers recorded their theories about what the stones represented, why they were there, local information and folklore. In Hampshire, for example, this

35. Bowen and Smith 1977, I86. 
Table 2. General characteristics of the 872 Sarsen Stones in Wessex records compiled by volunteer recorders, by county. ${ }^{\star}$ One Hampshire record is very clearly dated 1973, an obvious error on the part of the recorder, but cannot be re-attributed.

\begin{tabular}{|c|c|c|c|c|c|}
\hline CLASS & & Hampshire & Dorset & Wiltshire & TOTAL \\
\hline \multirow{3}{*}{$\begin{array}{l}\text { 'Utilised/not } \\
\text { utilised' }\end{array}$} & Utilised & 252 & $4 \mathrm{I}$ & 39 & 332 \\
\hline & Not utilised & $5 \mathrm{I}$ & 28 & $3 I$ & IIO \\
\hline & Not indicated & 8 & 63 & 359 & 430 \\
\hline \multirow[t]{6}{*}{ NGR } & no NGR & 2 & ० & 49 & $5 \mathbf{I}$ \\
\hline & 2-figure & ० & ० & I & $\mathbf{I}$ \\
\hline & 4-figure & 4 & I & II & 16 \\
\hline & 6-figure & 249 & 74 & IIO & 433 \\
\hline & 8-figure & 54 & 57 & 258 & 369 \\
\hline & Io-figure & 2 & 0 & o & 2 \\
\hline \multirow[t]{3}{*}{ Recorded names } & $\begin{array}{l}\text { Primary } \\
\text { recorder }\end{array}$ & 50 & I6 & I9 & 85 \\
\hline & $\begin{array}{r}\text { Secondary } \\
\text { recorder }\end{array}$ & 5 & 6 & 4 & $\mathbf{1 5}$ \\
\hline & Unattributed & I6 & 8 & 294 & 318 \\
\hline \multirow[t]{5}{*}{ Record date } & to day & 74 & $7 \mathrm{I}$ & 87 & 232 \\
\hline & to month & 194 & 46 & 9 & 249 \\
\hline & to year & II & o & 3 & $\mathbf{I 4}$ \\
\hline & unrecorded & 32 & I5 & 330 & 377 \\
\hline & Year range & $1973^{\star}-86$ & I974-5 & I974-6 & \\
\hline \multirow[t]{5}{*}{ Data source } & visit & $24 \mathrm{I}$ & II5 & 249 & 605 \\
\hline & bibliographic & I7 & 9 & $\mathrm{I} 32$ & 158 \\
\hline & own authority & IO & I & 3 & $\mathbf{I 4}$ \\
\hline & pers comm & 23 & 4 & II & 38 \\
\hline & unrecorded & 20 & 3 & 34 & 57 \\
\hline
\end{tabular}

included identification of sarsens as 'mark stones'36 and the tale of two thirsty sarsens in Twyford that drink from the river when the church bells ring. ${ }^{37}$

Various issues with the analogue records have longer-term archival implications. There is considerable variation in the visual quality of each record sheet, such as the handwriting, ink, legibility and text placement (see fig 3), as well as in the quality of the recorded content. As part of the original analysis, the records were collated and distribution maps for each county produced at I:I00,000. These showed sarsen locations coded by four general periods and as 'natural' stones, singly and as groups. Regrettably, these archived distribution maps are now compromised as the coloured markers stuck onto the sheets have lost their adhesion and fallen away (fig 4).

Archaeology enjoys a long history of public participation, including fieldwork by volunteers working at a national scale. Projects include, for example, the National Record of Industrial Monuments, ${ }^{38}$ the War Memorials Register, ${ }^{39}$ the Defence of

36. After Watkins $1925,23-33$.

37. SAL, MS $953 / 3 / 2 / \mathrm{I} / \mathrm{T} 8 \mathrm{a}$.

38. Buchanan I969, I97I.

39. Catherine Long, pers comm, 3 Aug 2017. 


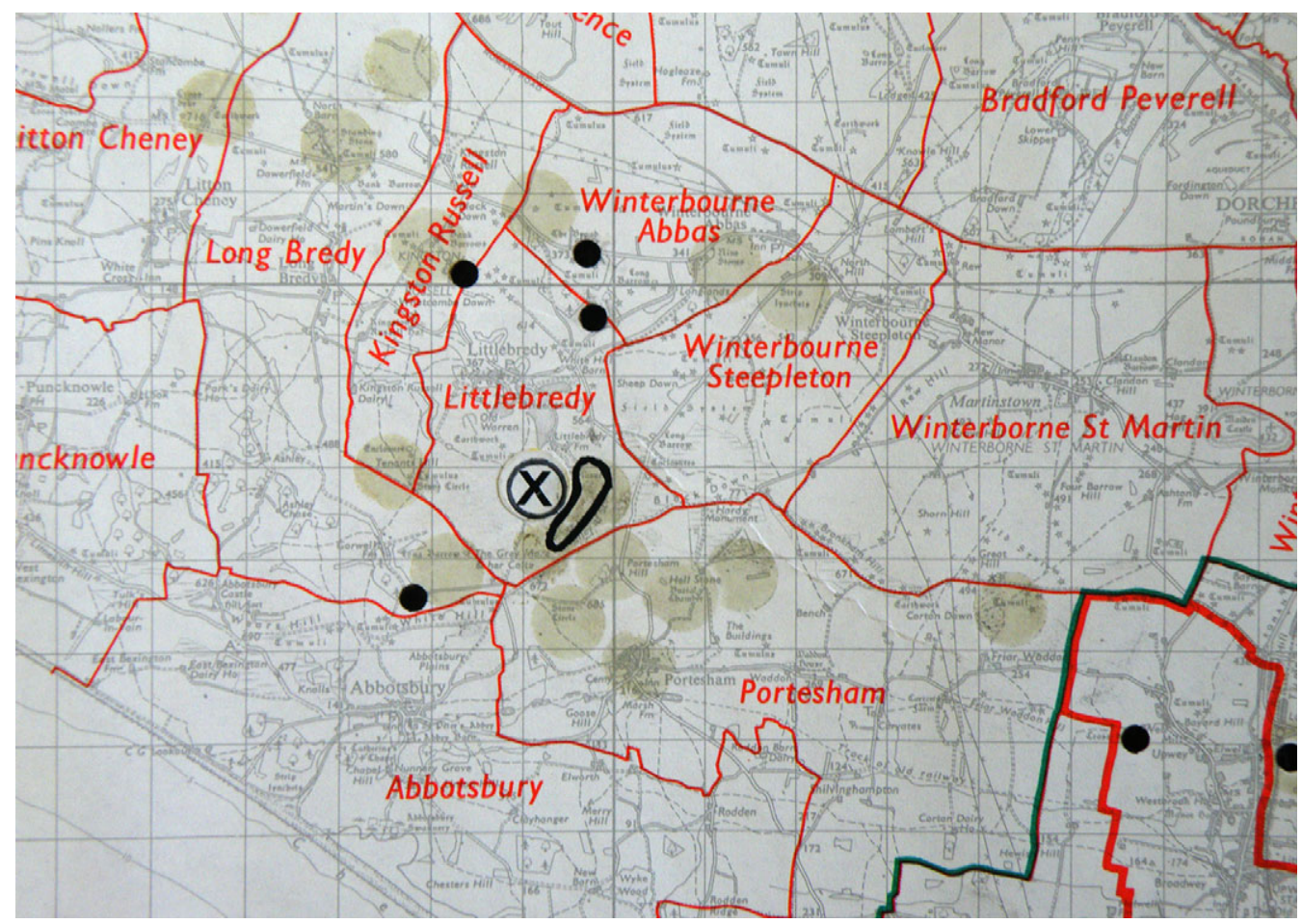

Fig 4. An extract from the Sarsen Stones in Wessex I:I00,000 distribution map for Dorset. Black dots show locations of single sarsen stones attributed to medieval, later and undated uses. The area outlined in black adjacent to the circled cross is the Valley of Stones in Littlebredy parish. Pale circular marks on the map show where coloured stickers once marked locations.

The stickers were colour-coded to indicate information including date of use (eg red for prehistoric), or sarsens that were documented in bibliographic sources but no longer present on the ground. SAL, MS953/2/2a-b. Reproduced with the permission of the Society of Antiquaries of London. Photograph: the author.

Britain Project ${ }^{40}$ and Home Front Legacy. ${ }^{4 \mathrm{I}}$ County-wide projects include Leicestershire's Community Heritage Initiative. ${ }^{42}$ The sarsen survey's time-limited, regional, subjectspecific fieldwork with a prehistoric focus stands out not only as a precursor to presentday collaborative citizen-science, but also for its ambition. It covered a big area and in a short space of time gathered a large dataset, drawing on multiple sources researched by a range of participants.

It is surprising that, despite the project's explicit aim to understand prehistoric relations with sarsen stone, no attempt was made to explore historical clearance of the stone and the undoubted relevance of this activity to interpreting the observable geological and archaeological records. An awareness of the potential to explore the historical industry is shown by a note typed in preparation for the 1975 Sarsen Symposium, tabling a report 
on 'evidence for movement/disappearance including unfinished splitting etc'. ${ }^{43}$ At the Symposium, Noel King described the industry but dwelt on the Nature Conservancy Council's interests on the Marlborough Downs. It is noticeable that none of the Tally Cards deal with the immense quantities of sarsen street furniture in villages and towns in the study area. The project team could legitimately claim to have created 'a picture of the present distribution of the stones' in the study area, but without any assessment of modern clearance the assurance that the data also show 'their probably maximum incidence on the surface, whether naturally or quarried, within the last 6,000 years' 44 is true only at the smallest of scales at which the project's maps were reproduced.

\section{The data}

The sarsen survey records are difficult to use as an analogue dataset and because of their variability. That includes the diversity of non-standardised record formats, absence of controlled recording language and different interpretations by volunteers around what should be recorded, and the heterogeneous nature of the collected data. Additionally, the I:IOO,০o0-scale distribution maps ${ }^{45}$ are compromised and cannot be used to replicate or interpret the published mapping. The published figures have their utility but are static, small-scale, black and white illustrations that cannot be interrogated in ways made possible by modern Geographic Information Systems. Accordingly, a digital dataset is required to employ the information contextually, for example with geological or historical basemapping.

Following an assessment of methodologies used by other archive projects digitising historical datasets, the complex visual properties of the Tally Cards were shown to preclude the use of scanning, computerised handwritten text recognition and data segmentation to create a digital dataset. A process of manual transcription was designed to capture data from the paper sarsen survey records in the Society of Antiquaries of London's collection MS 953 and from microfiche copies of that material held by the Historic England Archive. This exercise resulted in 872 separate records for individual sarsens, groups of sarsens and other features such as sarsen-built monuments. Data were transcribed following specific protocols into a spreadsheet comprising forty-five discrete fields, in which lengthy textual records were managed according to the precedent set by the British Museum's 'Micropasts' National Bronze Implements Index project. ${ }^{46}$ The detailed methodology, paradata and transcription protocols are publicly archived alongside an archive report. ${ }^{47}$

Various measures can be used to explore data quality across the total dataset and, bearing in mind differences in how data collection was co-ordinated in each area, between the three counties. This is important in order to judge the weight that may be placed on the archived data. Replicating Bowen and Smith's general distribution map of 'natural' ('not utilised') and anthropogenic ('utilised') sarsens ${ }^{48}$ demonstrates the difficulty of interpreting this classification. Figure 5 was produced using the total dataset (because it is not

43. HEA, SOAo3/18, Future Sarsen Programme. Note that italics in the text indicate a handwritten addition to the typescript.

44. Bowen and Smith 1977, I86.

45. SAL, MS953/2/2a-b, MS953/3/3/r, MS953/4/3a.

46. Bonnachi et al 2015; Jennifer Wexler, pers comms, I3 Aug and 5 Sept 2017.

47. Whitaker 2020a, 2020b, 2020c.

48. Bowen and Smith 1977 , I90 fig 2. 


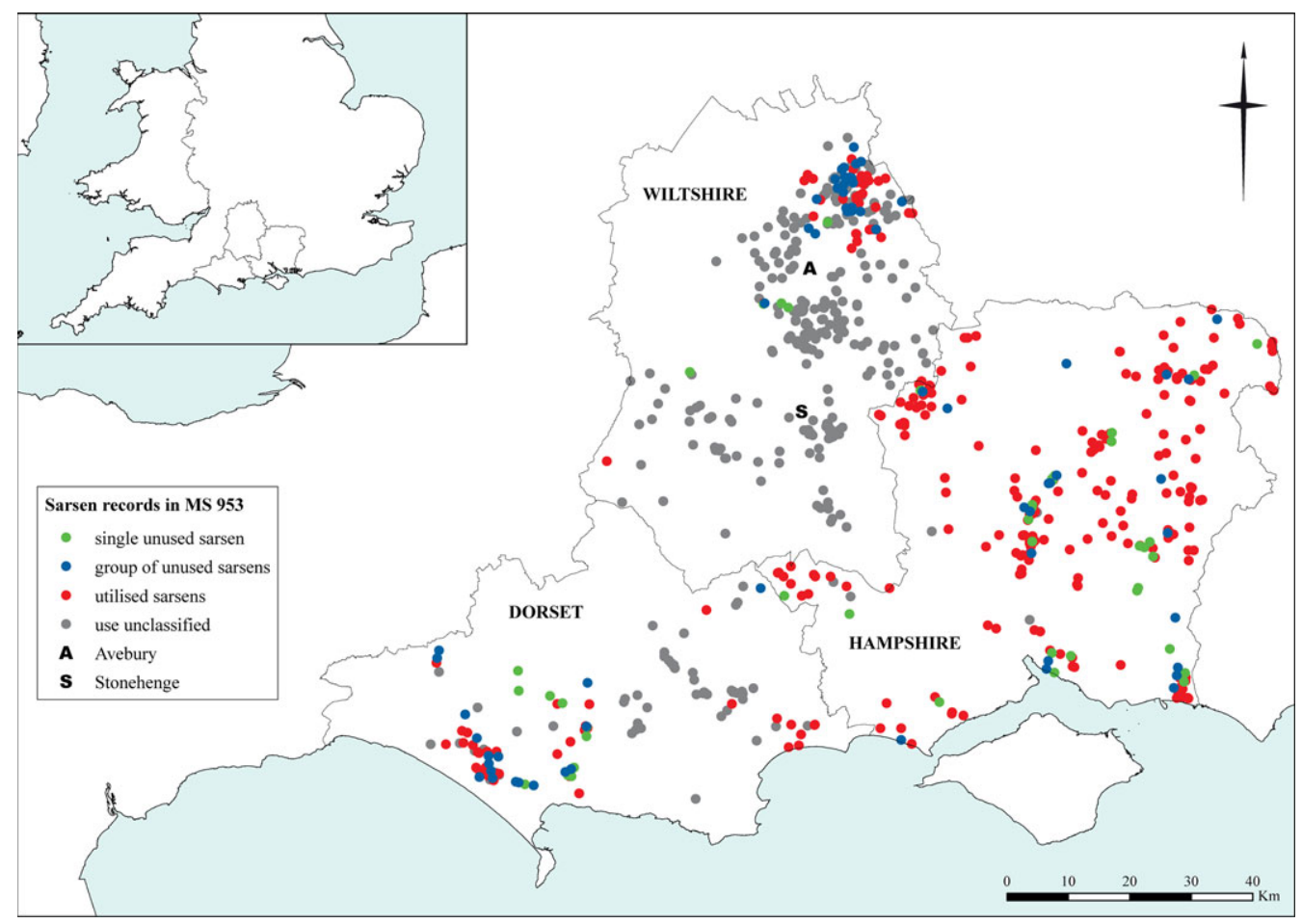

Fig 5. The distribution of all 872 digitised Sarsen Stones in Wessex project records. Bowen and Smith's original map published in 1977 displayed three classes: single natural sarsen; group of natural sarsens; utilised sarsen. Here, single and grouped unused sarsens (Bowen and Smith's 'natural' stones), utilised sarsen and the 430 records unclassed by volunteer recorders are shown. This dataset includes twenty-six records made after 1977 and may include duplicate records in the more complex Wiltshire subset. Includes Ordnance Survey data from 2017. Map: the author.

clear how Bowen and Smith selected points for their mapping). Of the 872 records, 332 (38 per cent) were marked as 'utilised', IIO (I3 per cent) as 'not utilised'; but in 430 records (49 per cent) this field went unrecorded (see table 2). An exact replica of the original map is thus not possible. Key differences include, for example, the presence in Hampshire of groups of 'not utilised' sarsens, whereas the map published in 1977 shows only single 'natural' stones. The missing records to the east and south of Avebury are clear. Nevertheless, the new version is broadly similar.

The quality of grid-references is another useful measure, assessed in terms of tolerance (that is, the percentage of grid-references recorded to 4-, 6-, 8- or Io-figures). Overall, the quality is high. In Hampshire, 303 (97 per cent) of records had 6- or 8-figure gridreferences; in Dorset, I3I (99 per cent); in Wiltshire, 368 (86 per cent). Although this measure is not one of accuracy, the large proportion of well-referenced records, given field recording without global positioning aids, is highly reassuring. Nearly 70 per cent of all records were the result of a field visit. The project's short timescale is reflected in the data collection date ranges, except for Peter Gallup's continuing research in Hampshire until I986.49

49. HEA, HSSoI, Hampshire Sarsen Survey. 
Table 3. The number of records created by the most active volunteers, by county, each volunteer making more than five Sarsen survey records.

\begin{tabular}{|c|c|c|c|c|c|}
\hline \multicolumn{2}{|c|}{ HAMPSHIRE } & \multicolumn{2}{|c|}{ DORSET } & \multicolumn{2}{|c|}{ WILTSHIRE } \\
\hline Volunteer & Records & Volunteer & Records & Volunteer & Records \\
\hline P W G & $130(43 \%)$ & N H F & $39(30 \%)$ & B P & $73(17 \%)$ \\
\hline M F H & $23(7 \%)$ & $\mathrm{C} \mathrm{J} \mathrm{B}$ & $35(27 \%)$ & I F S & $21(5 \%)$ \\
\hline D M B & I3 $(4 \%)$ & $\mathrm{D} \mathrm{Y}$ & I5 (II \%) & K F & $9(<3 \%)$ \\
\hline F O & II $(4 \%)$ & M J & $8(6 \%)$ & $\mathrm{J} \mathrm{B}$ & $6(<2 \%)$ \\
\hline S C & II $(3 \%)$ & R A P & $7(5 \%)$ & & \\
\hline G H S & $9(<3 \%)$ & & & & \\
\hline J C D & $7(<3 \%)$ & & & & \\
\hline M C & $6(<2 \%)$ & & & & \\
\hline M D & $6(<2 \%)$ & & & & \\
\hline unattributed & I6 (5\%) & & $8(6 \%)$ & & $294(69 \%)$ \\
\hline
\end{tabular}

Although 377 (43 per cent) of records went undated, it is possible to profile much of the fieldwork to the day or month of the year (48I records, 55 per cent) (see table 2). Characteristics such as these suggest that confidence in the general dataset is warranted.

A feature of many modern digital crowd-sourced projects, such as 'Micropasts', is that a small number of participants create the greatest number of records. ${ }^{\circ} \mathrm{A}$ modest evaluation of this aspect of the dataset is possible by recording the survey's volunteer names (table 3 ). Although 3 I 8 ( 36 per cent) of all records were unattributed, the rest have a named primary recorder and sometimes a second partner (see table 2). Overall, a small number of volunteers did make the most records. In Hampshire, Peter Gallup recruited the biggest team, but made the most records himself (I30 records, 43 per cent of Hampshire). John Bailey, who made thirty-five records (27 per cent of Dorset) recruited fewer volunteers there and shared much of the workload with $\mathrm{N} \mathrm{H}$ Field (39 records, 30 per cent). Wiltshire had a similar number of volunteers as Dorset, but 294 (69 per cent) of the records are unattributed (see table 3). This figure is tied to the use of notes and postcards in Wiltshire. That county's dataset largely lacks the specially designed Tally Cards (see table I) that included the prompt to record the volunteer's name.

It is also possible to assess the extent to which gaps in the map are due to absence of sarsen, or simply reflect where the volunteers worked. The most prolific volunteers working in Dorset and Hampshire were quite well-spread across those counties (fig 6), prompting more confidence in the survey coverage. In Wiltshire, the overall volume of records across the county is encouraging. Gaps in areas ST92 (south-west Wiltshire, between Shaftesbury and Fovant) and ST93 (west Wiltshire, between Hindon and Wylye) are explicitly explained in two notes confirming that the five volunteers searching there found no sarsens. ${ }^{5 \mathrm{I}}$ But the majority of attributable records in Wiltshire were made by Bernard Phillips, working only in the Swindon area (73 records, I7 per cent of Wiltshire) (see table 3). Furthermore, only 249 ( 58 per cent) of Wiltshire records were derived from field visits (see table 2). This suggests that particular care should be taken to review the Wiltshire data, interrogating the bibliographic sources that were so heavily used and characterising 


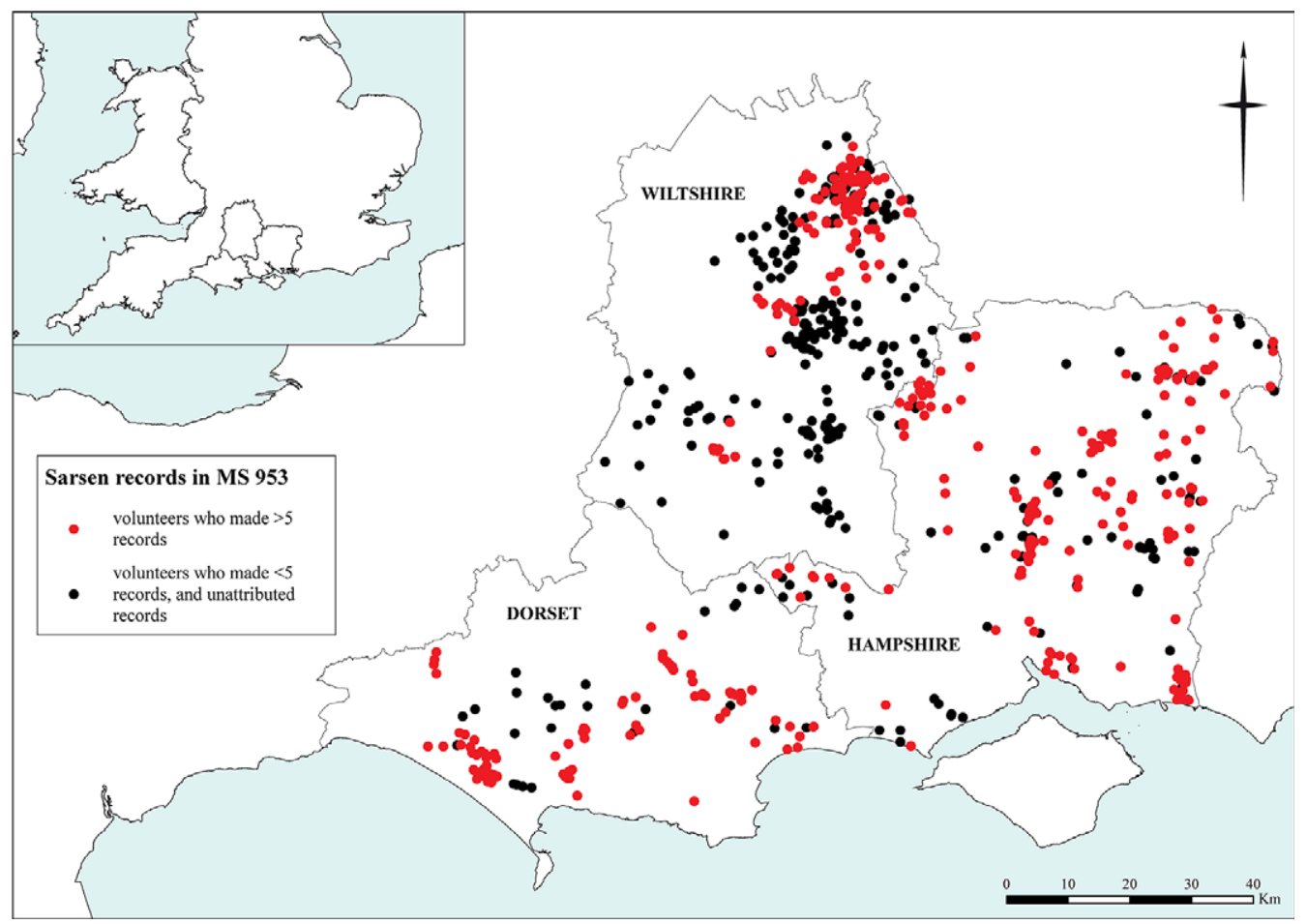

Fig 6. The distribution of all 872 digitised Sarsen Stones in Wessex project records distinguishing the most prolific volunteers. Includes Ordnance Survey data from 20I7. Map: the author.

how the sarsen profile in Wiltshire differs from Dorset and Hampshire because of these recording practices.

Portesham (Dorset) provides a useful case study of aspects of the volunteers' practice and presents a means to reflect on the Sarsen project's stated aims. A large parish in the south of the county, Portesham's solid geology spans the late Jurassic to late Cretaceous, with an area of Tertiary Bracklesham/Barton Group deposits forming the highest hills to the north (fig 7). It lies immediately to the south-east of a surviving sarsen spread in Littlebredy parish. Portesham's records are for a mix of 'natural' sarsens recorded singly and in groups, prehistoric monuments and extensive sarsen use in more recent structures. Seventeen distinct records were made here, by three volunteers working from April I974 to May 1975. No notes explain whether the large gaps were searched to no avail, or could not be accessed. The Tally Cards include material gathered from earlier published authorities, which the volunteers ground-truthed, as well as seeking out new data. The volunteers adapted their observations to the Tally Card format, resulting in a rich record including quotations from antiquarian authorities and in-person reports.

Two original reference numbers include multiple entries: PRT6 (Portesham village) and PRT7 (Black Down Barn area) account for ten of the records mapped in fig 7. In PRT6, one sarsen (Do82) was visible as the result of recent building demolition. Two stones mapped by the Ordnance Survey in 1902 (Do79) could not be found. There were very many stones in building fabric (Do77, Do78, Do80, Do8I). This included a long wall along the west side of Front Street and garden walls on the east side including more than 
(a)

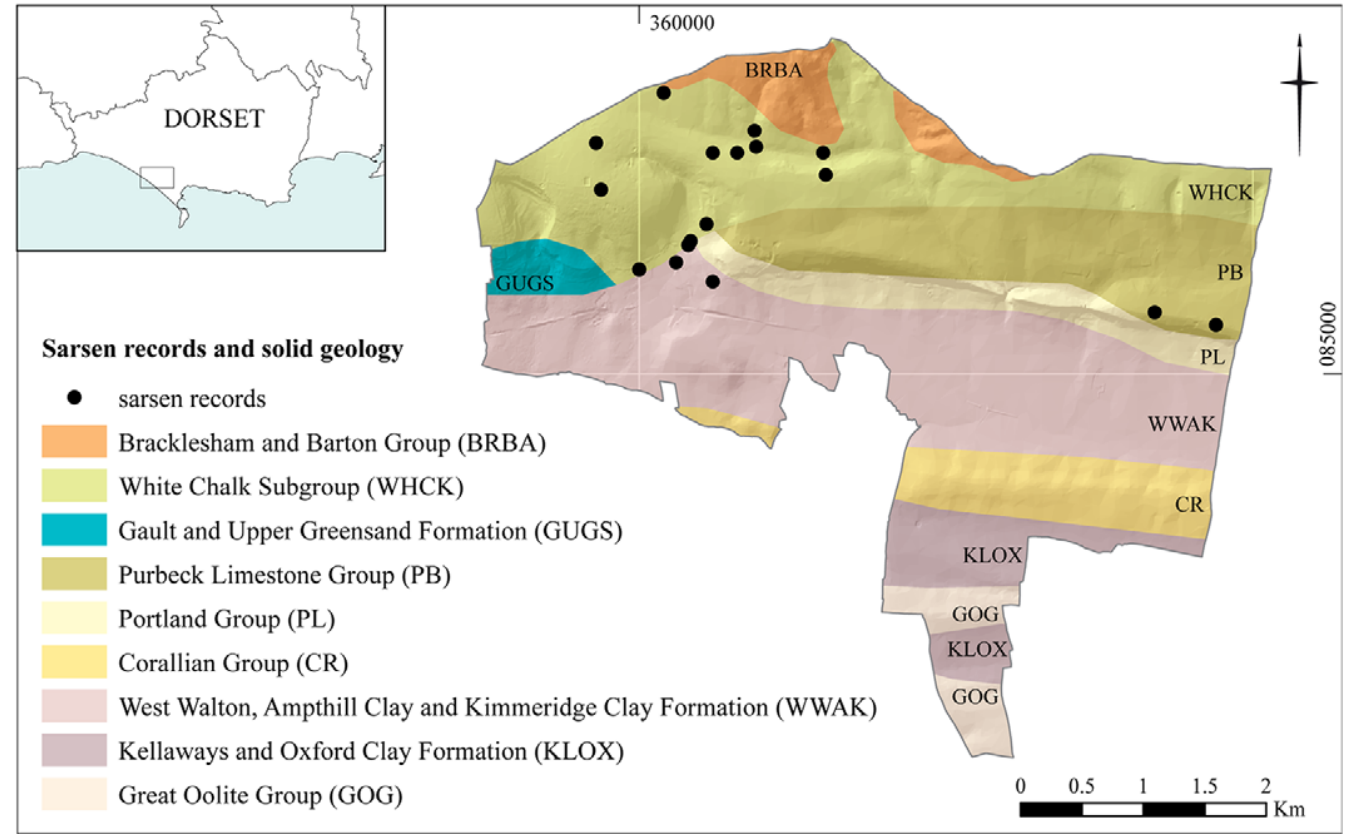

(b)

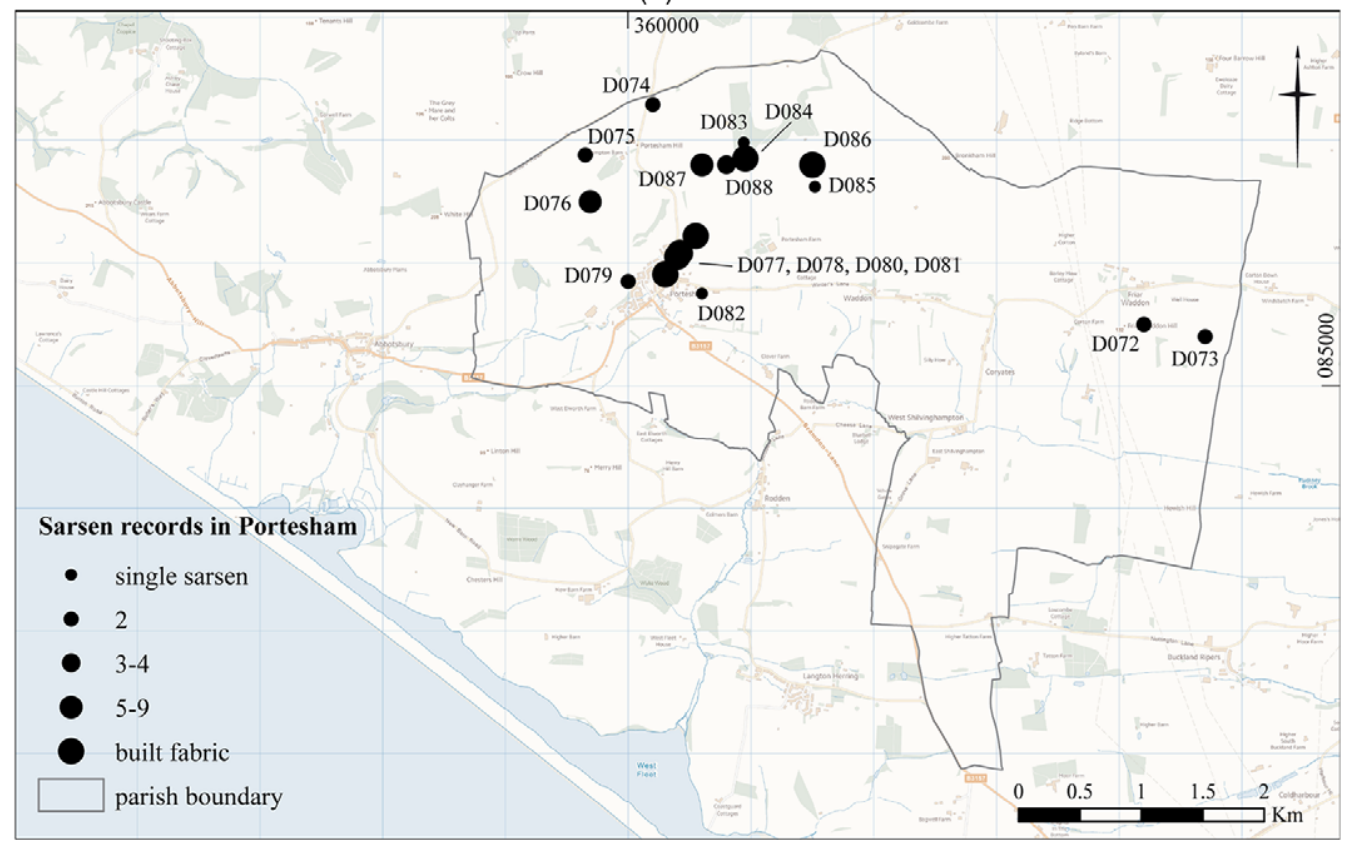

Fig 7. (a) The solid geology of the large parish of Portesham (Dorset) includes Cretaceous and Palaeogene rock units with which sarsen stone is commonly associated. (b) A short distance to the south-east of Dorset's large natural sarsen spread in the Valley of Stones, Portesham includes sarsens used in multiple ways since prehistory. See text for details of records numbered Do72 to Do88. Includes Ordnance Survey data from 2017 and

British Geological Survey data from 2018. Maps: the author. 
I60 sarsens (Do80), and field walls on Portesham Lane (Do8I). Amongst PRT7, one sarsen (Do83) was seen in a hilltop plantation but the other three reports in this record are also structural. Do84 records sarsens used in agricultural building fabric, Do85 refers to a single stone spotted in a field wall, and Do86 includes more than 250 sarsens counted in field walls. On I6 September 1974, volunteer M Jackson noted in Do84: 'farmworker said pasture grass of the field had been re-laid in past with great difficulty as many "boulders" just beneath the surface of the ground ... [in] the field of the Hell Stones [Do87] the ploughing is extremely difficult because of the numbers of large rocks below the surface of the ground. 52

In other records, Do72 and Do73 in the east of the parish represent four sarsens described as 'not utilised' (ie 'natural'), partially visible in the turf on the hilltop. One of the pair in Do72 was 8ft long $(2.4 \mathrm{~m})$. Combined with Do74, two large 'not utilised' stones recorded by John Bailey as 'intermediate Valley of Stones and Black Down group',53 this suite of records strongly suggests a once far greater presence of sarsen extending southeast of Littlebredy's surviving sarsen spread, in fields long-since cultivated. Taking this closer look at the richer information available in the records shows how the Sarsen survey made progress towards its first aim, to establish sarsen's former incidence. ${ }^{54}$

The second objective, to document prehistoric sarsen uses, was also addressed in Portesham. Four monuments incorporating sarsens were recorded in the parish. Do75 records the remains of the long barrow ${ }^{55}$ on the hilltop close to Do76, Hampton Stone Circle. ${ }^{56}$ On the hill opposite to the east is Do87, the Hell Stone long barrow, ${ }^{57}$ whilst Do88 marks the location of the former stone setting 'Jeffrey and Joan and their dog Dinty and Eddy'. ${ }^{8}$ In his record for Do85, M Jackson noted 'Celtic' fields in the environs, on the north-facing slope of the valley defined by the spur of high ground running east-west from Portesham Hill. This sort of information was a Tally Card class intended to flag up possible co-locations of sarsens and other features, including early field systems.

\section{DISCUSSION}

\section{Landscape archaeology}

The concept of landscape archaeology, founded on the doing of field archaeology as exemplified by Aston and Rowley in their seminal book Landscape Archaeology, ${ }^{59}$ forms the Evolution project's contemporary intellectual setting. Although not calling itself 'landscape archaeology', the Evolution project as conceived, and its Sarsen survey as executed, can both be placed firmly in the context of increasingly panoptic approaches to archaeological fieldwork in the twentieth century. Here is it important also to draw on the

52. SAL, MS953/2/I/PRT7.

53. SAL, MS953/2/I/PRT3.

54. Bowen and Smith $1977,185,190$.

55. HE, scheduled monument DO507; Dorset HER I 090044.

56. HE, scheduled monument DO46; Dorset HER I 090058.

57. HE, scheduled monument DO87; Dorset HER I 090033.

58. Dorset HER I 090085.

59. Aston and Rowley 1974, I9-24. 
professional history of Collin Bowen in particular, his recognition of the extensive archaeological record visible on the ground and from the air, and his realisation of its vulnerability.

Dalglish has identified three axiologies of landscape ${ }^{60}$ - three ways of locating value encompassing ethics and aesthetics amongst the web of agents, practices and being that comprise 'landscape' - each of which defines landscape differently. Archaeologists have conceptualised landscape according to all three: anthropocentrically, prioritising human interests in an objectified and commodified natural resource; environmentally, emphasising inherent value in the non-human world; and relationally, by denying, removing, connecting or eliding the human-non-human dyad that has tended to put 'natural' and 'cultural' landscapes in tension or contradiction. ${ }^{6 \mathrm{I}}$ Prior to more recent relational approaches, archaeologists have tended to adopt anthropocentric or environmental axiologies in which landscape, conceptualised as a material object, is susceptible to mensuration, recording and interpretation, especially in functionalist, adaptive, exploitative terms. ${ }^{62}$

Characteristics of an anthropocentric landscape axiology, in which field survey methods can be brought to bear on landscape-as-object in order to reveal how people adapted to, or exploited, the environment, inhabit the language of the Evolution project proposals and the Sarsen survey. The use of that key word palimpsest, introduced to archaeologists by Crawford ${ }^{63}$ and popularised by Hoskins, ${ }^{64}$ speaks to the project proposers' conceptualisation of landscape as 'hand-made artefact'.${ }^{65}$ For example, Bowen's intention to quantify natural phenomena (sarsens) envisioned as hindrances to the first people to have established ownership of the land by its division, was driven by the idea that fragments of the first-written landscape remain, and the possibility of unpicking these through meticulous survey.

The Portesham results fulfilled expectations of anthropocentric and environmental landscape axiologies. Its palimpsest as captured by Sarsen survey volunteers included the underlying geology, determining the presence of boulders in the parish. These had been exploited as useful resources at different times in over-written sequences of prehistoric monument building and more recent settlement structures and boundaries. The undertext included prehistoric field systems; but there was also confirmation of difficulties presented by the geology to agricultural practice, through the testimony of a modern farmworker. The volunteer-collected data showed how people had exploited, and adapted to, the environment.

The Sarsen survey in particular was formulated and driven by Collin Bowen (I9I9 -20II), an investigator with the Royal Commission on the Historical Monuments of England (RCHME) from 1949, who since I952 had been collecting and enumerating archaeological features parish by parish for the Commission's Dorset Inventory volumes. Bowen was celebrated for his superior fieldcraft, described as 'a level of analytical fieldwork that never before had been achieved even by those of the stature of Crawford' ${ }^{66}$ For Bowen this was not only a metaphorical patrimony in the British field archaeology tradition maintained by the $\mathrm{RCHME},{ }^{67}$ but also a literal one in his friendship with and likely pupillage by

60. Dalglish 2012.

6I. Ibid, 329-33.

62. Darvill 2008, 6I-2; Dalglish 20I2, 333-4; Thomas 20I2, 98.

63. Crawford 1953.

64. Hoskins 1955.

65. Gillings and Pollard 20I6b, II.

66. Taylor 2010, 85.

67. Ashbee 1972; Bowden 1999. 
O G S Crawford himself. ${ }^{68}$ His approach to archaeology was characterised by his obituarist: 'No books, no theory, just detailed fieldwork on archaeological sites.' ${ }^{\prime} 9$

Believing that the first farmers in Britain encountered and transformed a heavily wooded environment, archaeologists reasonably anticipated confirmation of Neolithic origins of prehistoric field systems. ${ }^{70}$ These expectations permeate a number of the papers given at contemporary conferences including in 1969 'Economy and Settlement in Neolithic and Early Bronze Age Britain and Europe',71 the 'Highland Zone' in 1974 and 'Lowland Zone' (1975) Effect of Man on the Landscape meetings. ${ }^{72}$ Bowen shared this interest in prehistoric field systems. ${ }^{73}$ The rationale of the Evolution project and the Sarsen survey depended on his anthropocentric understanding of the agricultural processes leading to the formation of these archaeological features. His concern with stone clearance was underpinned by his assumptions about what the first farming looked like: the lowest layer of the palimpsest had to have been inscribed by clearing and breaking up ground, because, according to Bowen, that was the first requirement of agriculture 'for all periods'. ${ }^{74} \mathrm{His}$ original objective for the survey was to assess this essential clearance by recording how and where the sarsens had been used. ${ }^{75}$ With Peter Fowler, Bowen had already encountered sarsens buried in lynchets during their work on the Marlborough Downs in Wiltshire. Finds including early Neolithic bowl pottery excavated from their cutting through one such field boundary ${ }^{76}$ implied that there had been Neolithic activity in the area, perhaps prompting Bowen's thoughts about sarsen's nuisance value to pioneering agriculturalists.

In Portesham, however, the presence of prehistoric sarsen-built monuments in an area including prehistoric fields challenged Bowen's key assumptions. Bowen and his colleagues had recorded numerous field groups in and around Portesham, ${ }^{77}$ and it was an area he referred to in Ancient Fields. ${ }^{78}$ Here, the palimpsest's undertext thus comprised evidence for sarsen exploitation as a resource (for the earliest monument building), and no clear evidence that a discouraging stony presence had directed early cultivation elsewhere. The difficulty lay in both the problematically-long date range of 'Celtic' fields, defined as 'all fields of regular shape laid out before the Saxon conquest', ${ }^{79}$ and also the expectations that underpinned the survey's stated aims, derived from an anthropocentric concept of landscape.

In notes accumulated in his project filing, Bowen wrote:

Do sarsens attract interest. They didn't make people avoid. Two points we began with were

a) nuisance value b) challenge to utilisation.

68. Taylor $2010,87$.

69. The Times $201 \mathrm{I}$.

70. For example, Evans 1971; Fowler I971; Pryor 1978.

7I. Simpson I97I.

72. Evans et al 1975; Limbrey and Evans 1978.

73. Bowen I96I.

74. Ibid, 5 .

75. HEA, SOAo3/r8, memoranda written by Collin Bowen dated 23 Nov and 20 Dec 1973.

76. Bowen and Fowler 1962, I05.

77. RCHME I970, 622-34.

78. Bowen I96I, pl $2 b$.

79. RCHME I970, 622. 
- $\quad$ sarsens are utilised in all periods

- orthostats and large stones are restricted Neo/BA

- the earliest therefore for the [...] of sarsens as boulders is Neo

- the earliest [...] for the breaking up of sarsens is also NEO

\section{Nuisance/utilisation: Did they attract??!! GEOL SURFACE CONCS NOT AVOIDED BUT OCCUR WHERE EARLY NODAL CONCS AVEBURY, VALLEY OF STONES ${ }^{80}$}

Although his crabbed handwriting is difficult to interpret ('CONCS' is probably shorthand for 'concentrations'), not only was Bowen forced to conclude that sarsens presented no impediment to early farming (in the terms in which that farming was understood at the time), these manuscript notes also suggest that Bowen began to consider the possibility that the sarsens themselves drew people into certain locations, including north Wiltshire.

The archaeological record, revealed and under threat

The relationship between the aims of the Evolution of the Landscape project and the Sarsen survey results remained unspoken, as the parent-project faded away in the later I970s. This is not the only reason, however, that the survey results were not related more closely to the Evolution project's aim to understand 'the whole time-conditioned environment' ${ }^{8 I}$ The empiricist approach taken towards both projects, in which Bowen at least saw it as essential to collect as much data as possible, despite openly acknowledging the crippling resource required, was problematic. Whilst seeking to move beyond studies of individual monuments in the hope of understanding past populations' economic and social organisation from more wide-ranging data, ${ }^{82}$ the projects were under-theorised in how their empiricist methodology would cast light on the past.

The contiguity of the archaeological record was well-established in Bowen's mind through decades of fieldwork and studying aerial photographs. Having driven RCHME survey practices towards detailed description and interpretation, ${ }^{83}$ he was moving conceptually ever further from the restrictions of monument-based inventorying within parish boundaries to wider landscapes, as indicated by his work on Bokerley Dyke. ${ }^{84}$ His colleague Barry Cunliffe had done the same through an extensive survey of 'the total settlement pattern' of Chalton (Hampshire). ${ }^{85}$ The call for the Evolution project to make 'a total search $^{\prime 86}$ (original emphasis) of $c \mathrm{I}, 500$ square miles of ground with air photograph analysis to plan archaeological features chimes with the 'Total Archaeology' and 'total landscape' of Bowen's RCHME colleague, Christopher Taylor. ${ }^{87}$ By this, Taylor meant a multi-period and landscape-scale approach to research, going beyond a narrow single-site focus.

80. HEA, SOAo3/16, Sarsens. Notes.

8I. HEA, SOAo3/r8, Society of Antiquaries. Evolution of the Landscape Project.

82. Bowen and Cunliffe I973, 9.

83. The Times $201 \mathrm{I}$.

84. Martyn Barber, pers comm, 26 Jul 2017.

85. Cunliffe 1973.

86. Bowen and Cunliffe I973, IO.

87. Taylor I974, I5O-I. 
He emphasised bringing, for example, geomorphology, art-history and place-names to mapping to 'trace the ebb and flow of agriculture in an area for 2,000 years' ${ }^{88}$

In contemporary excavation, a similar approach was espoused by, for example, David Clarke in 1975 at Great Wilbraham ${ }^{89}$ and by Margaret and Tom Jones working at Mucking from 1965 to $1978 .{ }^{90}$ Investigating Mucking's extensive archaeology, Margaret Jones was confronting outmoded concepts of bounded site and monument whilst aspiring to Ioo per cent excavation. Like Taylor, Clarke also advocated the assembly of diverse datasets to understand a 'totality' of evidence. Clarke's intention was to develop a scientific interdisciplinarity in partnership with expert colleagues from areas including botany and quaternary science. The extended Evolution project proposal authored by Barry Cunliffe, John Coles and Collin Bowen mentions a similarly wide-ranging set of interests and specialists, ${ }^{9 \mathrm{I}}$ including Geoffrey Kellaway (geology), David J Carter and Keith Barber (geography), Geoffrey Dimbleby and John Evans (environmental archaeology), Annie Grant and J Gaitens (osteo- and zoo-archaeology). As Bowen put it, 'we are a multidisciplinary project'. ${ }^{2}$

In I960, Bowen had co-authored the highly influential $A$ Matter of Time, ${ }^{93}$ using aerial photography to identify the rapid loss by quarrying of archaeological remains in river valley gravels. The aerial evidence had finely attuned his understanding of risks to historic landscapes. Threat similarly permeates the tone of the Evolution project's archived papers. A general threat to the archaeological resource, including explicit references to prioritising Society of Antiquaries' budgets, underpinned the justification for the Evolution of the Landscape project. Threats to sarsens in particular were at the forefront of Bowen's mind. For example, he wrote to friends and colleagues on 23 November 1973 lamenting sarsen clearance by the estate manager from an area north of Old Totterdown (Wiltshire), commenting, 'It seems further to illustrate the desirability of listing all such sites in a way that would ensure archaeological/geological examination before destruction' ${ }^{94}$ On 20 December he followed this with the need to identify ownership to discourage stone clearance. ${ }^{95}$

The point was emphasised in the Information Sheet issued to project volunteers. ${ }^{96}$ Attendees of the Sarsen Symposium agreed that intelligence about sarsen destruction should be passed on to the Society's Secretary so that investigations could be arranged. ${ }^{97}$ Even in $1978,9^{98}$ Bowen was pursuing correspondence with the National Trust regarding a local farmer's clearance of sarsens from land close to the protected spread in Piggledene (Wiltshire). Concern at the loss of sarsens from 'natural' spreads by agricultural clearance could be said to have begun with Colt Hoare, ${ }^{99}$ but it came to a head with the early twentiethcentury campaign to protect sarsens from quarrymen working in Lockeridge and Piggledene

88. Ibid, I50.

89. Evans et al 2006, II8.

90. Evans et al 20I6, 2.

9I. SAL, MS953/I/I, Proposal for sponsorship of a scheme of research by the Society of Antiquaries of London.

92. HEA, SOAo3/or, Evolution of the Landscape 23 Feb 1973.

93. RCHME I960.

94. HEA, SOA03/18, memorandum written by Collin Bowen dated 23 Nov 1973.

95. HEA, SOA03/18, memorandum written by Collin Bowen dated 20 Dec 1973.

96. HEA, SOAoz/oI, Evolution of the Landscape, Wessex Pilot Scheme News Sheet No. I.

97. HEA, SOAo3/o3, Sarsen Symposium, Evolution of the Landscape Project News Sheet No. 2.

98. HEA, SOAo3/03, letter written by Frank Swanton dated 2I Feb I978.

99. Colt Hoare, I8I9. 
in Wiltshire. ${ }^{100}$ 'Those who have watched the district through this century,' wrote local observer H C Brentnall, 'have seen the wolf at work in many a fold of the grey-wethers.' ${ }^{\circ}$ This sarsen advocacy formed the backdrop to Bowen's angst.

The Society of Antiquaries' need to respond to these threats, Bowen's call for detailed extensive survey in the manner of 'total archaeology' as the extent of the record became clear and his personal concern for sarsen stones are similarly reflected in a contemporary call to arms by Aston and Rowley. They wrote, 'Scholars in the future may have the leisure to analyse and synthesise, but at the moment we are all in the front line', calling for 'comprehensive regional archaeological distribution maps'. ${ }^{\text {IO2 }}$ In this sense the Society's research, promoted by Bowen and his peers, exemplifies the contemporary awareness of archaeological loss ${ }^{\mathrm{IO} 3}$ and the requirement to collect data that prompted the establishment of local authority Sites and Monuments Records at that time. ${ }^{\text {IO }}$

\section{CONCLUSION}

Collin Bowen was an important figure, influencing a generally more frequently published generation of researchers like Corney, Fowler and Taylor, ${ }^{105}$ for whom, as Gillings and Pollard remark, ${ }^{106}$ the idea of landscape archaeology and history arguably seemed straightforward. He held an anthropocentric concept of landscape as a resource to be tapped by the first farmers, and an object of partial features that could nevertheless now be observed, measured and represented if only they could be salvaged in time. The Evolution project has those Hoskinian hallmarks of landscape archaeology identified by Johnson: ${ }^{107}$ deeply empirical practices employed by surveyors not afraid to dirty their walking-boots to study a landscape of immense age, beguiled, as Johnson suggests, ${ }^{108}$ by the idea of the palimpsest.

The Evolution of the Landscape project was an aspirational response to some of archaeology's most pressing cultural resource management problems of the later twentieth century, including the impact of industrial agriculture and large-scale infrastructure development destroying un-researched archaeological evidence. Society of Antiquaries' Fellows were concerned about how to dispose finite research grants in the face of widespread threats to an archaeological record that had been extended physically by aerial photographic evidence and conceptually by the leap from 'site' to 'landscape'. Collin Bowen was a significant contributor to this understanding and the driving force behind the project's proposals, attempting to harness multi-disciplinary research to tackle the idea of 'total landscape'.

The Sarsen survey struggled partly because of the limitations of its anthropocentric landscape axiology and partly because of difficulties in handling its highly heterogeneous analogue data in all its varied formats. In fact, the project's aim to explore how sarsen stones had been dealt with by the first farmers was tantamount to an unspoken

I00. Goddard and Bouverie 1908.

IOI. Brentnall I946, 424.

I02. Aston and Rowley I974, I2, 25.

103. Rahtz 1974.

I04. RCHME I993.

I05. Fowler I978; Taylor I983; Corney 2000.

I06. Gillings and Pollard 20I6b.

I07. Johnson 2007.

I08. Ibid, 58 . 
acknowledgement that the boulders themselves had been active agents in Neolithic and later lifeways. But the absence of a concept of, for example, agential stones in the sense of, say, Richards, ${ }^{109}$ or an ambiguity of natural-cultural place, ${ }^{\text {IIO }}$ hindered the extent to which the datasets could be applied to the objectives articulated in 1972 and 1973.

Nevertheless, the public archaeology methodology was ambitious in its response to a research burden that could not be met by the professional sector. The valuable archive resource is strengthened by the myriad notes that back up the volunteers' individual records and considerable weight can be placed on their observations. The survey's large dataset presents some difficulties in both its heterogeneity and current physical condition, but, approached with the spirit of contingency and creativity encouraged by Evans et al, ${ }^{\text {III }}$ and in digital form, the data can more easily be visualised and interrogated in order to play a part in informing our perceptions of sarsen-scapes. Thanks to collections cared for by the Society of Antiquaries of London and Historic England, new life can be breathed into old archaeological archives.

\section{ACKNOWLEDGEMENTS}

This work was supported by the Arts and Humanities Research Council (grant number AH $\backslash L_{503939} \backslash \mathrm{I}$ ) through the South, West and Wales Doctoral Training Partnership. The author thanks the Society of Antiquaries of London and Historic England for access to archive collections; Martin Bell, Jim Leary and Josh Pollard for commenting on previous drafts of this paper; and the anonymous reviewers who kindly provided feedback. Any errors remaining are the author's own.

\section{ABBREVIATIONS AND BIBLIOGRAPHY}

\section{Abbreviations}

$\begin{array}{ll}\text { HE } & \text { Historic England } \\ \text { HEA } & \text { Historic England Archive } \\ \text { HER } & \text { Historic Environment Record } \\ \text { RCHME } & \text { Royal Commission on the Historical Monuments of England } \\ \text { SAL } & \text { Society of Antiquaries of London }\end{array}$

\section{Bibliography}

\section{Primary sources}

HEA, Swindon, HSSoI, Hampshire Sarsen Survey

HEA, Swindon, RCHME Microfiche, Wessex Sarsen Survey
HEA, Swindon, SOAo3, Sarsen Stones in Wessex

SAL, MS953, Wessex Sarsen Survey

I09. Richards 2013.

IIO. For example, Bradley 2000; Harmansah 2014.

III. Evans et al 2016, 526-30. 


\section{Secondary sources}

Ashbee, P 1972. 'Field archaeology: its origins and development', in P J Fowler (ed), Archaeology and the Landscape, John Baker, London

Aston, $\mathrm{M}$ and Rowley, $\mathrm{T}$ 1974. Landscape Archaeology: an introduction to fieldwork techniques on post-Roman landcapes, David and Charles, Newton Abbot

Bell, M r983. 'Valley sediments as evidence of prehistoric land-use on the South Downs', Proc Prehist Soc, 49, II9-50

Bonnachi, C, Bevan, A, Pett, D and KeinanSchoonbeart, A 2015. 'Crowd- and community-fuelled archaeology: early results from the Micropasts project', in F Giligny, F Djindjian, L Costa, P Moscati and S Robert (eds), Proceedings of the 42nd Annual Conference on Computer Applications and Quantitative Methods in Archaeology, CAA 2014, 279-88, Archaeopress, Oxford

Bowden, M 1999. Unravelling the Landscape: an inquisitive approach to archaeology, Tempus, Stroud

Bowen, H C 1961. Ancient Fields: a tentative analysis of vanishing earthworks and landscapes, The British Association for the Advancement of Science, London

Bowen, H C and Cunliffe, B I973. 'The Society's research projects', Antiq $\mathcal{F}, 53,9-13$

Bowen, H C and Fowler, P J I962. 'The archaeology of Fyfield and Overton Downs, Wiltshire (interim report)', Wiltshire Archaeol Natur Hist Mag, 58, 98-II5

Bowen, H C and Smith, I F 1977. 'Sarsen Stones in Wessex: the Society's first investigations in the Evolution of the Landscape project', Antiq F, 57, I85-96

Bradley, R 2000. An Archaeology of Natural Places, Routledge, London

Brentnall, H C I946. 'Sarsens', Wiltshire Archaeol Natur Hist Mag, 5I, 4I9-439

Buchanan, R A 1969. 'The national record of industrial monuments', in $\mathrm{N}$ Cossons and K Hudson (eds), Industrial Archaeologists' Guide 1969-70, II-I4, David and Charles, Newton Abbot

Buchanan, R A 197I. 'The national record of industrial monuments', in $\mathrm{N}$ Cossons and $\mathrm{K}$ Hudson (eds), Industrial Archaeologists' Guide I97I-73, 23-30, David and Charles, Newton Abbot

Causer, $\mathrm{T}$ and Wallace, $\mathrm{V}$ 20I2. 'Building a volunteer community: results and findings from transcribe Bentham', Digital Hum Q, 6, <http://www.digitalhumanities.org/dhq/ $\mathrm{vol} / 6 / 2 / 000 \mathrm{I} 25 / 000 \mathrm{I} 25 \cdot \mathrm{html}>$ (accessed I8 May 2020)

Colt Hoare, R I819. The Ancient History of Wiltshire, Lackington, Hughes, Harding, Mavor and Jones, London

Corney, M 2000. 'Characterising the landscape of Roman Britain: a review of the study of Roman Britain 1975-2000', in D Hooke (ed), Landscape, the Richest Historical Resource, Supp Series I, 32-45, The Society for Landscape Studies, Exeter

Council for British Archaeology 20I4. 'Home Front Legacy: about the project', Home Front Legacy, <https://www.homefrontlegacy. org.uk/wp/about-the-project/> (accessed 3I Jan 20I8)

Council for British Archaeology 2017. 'Defence of Britain archive', Archaeology Data Service <http://archaeologydataservice.ac. uk/archives/view/dob/> (accessed 7 Sept 2017)

Crawford, O G S I953. Archaeology In The Field, Phoenix House, London

Cunliffe, B r973. 'Chalton, Hants: the evolution of a landscape', Antiq F, 53 (2), I73-90

Cunliffe, B 2000. The Danebury Environs Programme: the prehistory of a Wessex landscape, Institute for Archaeology, Oxford

Dalglish, C 2012. 'Archaeology and landscape ethics', World Archaeol, 44, 327-4I

Darvill, T 2008. 'Pathways to a panoramic past: a brief history of landscape archaeology in Europe', in B David and J Thomas (eds), Handbook of Landscape Archaeology, 60-76, Routledge, London

Evans, C, Appleby, G, Lucy, S, Appleby, J and Brudenell, M 20I6. Lives in Land. Mucking excavations by Margaret and Tom fones, 1965-1978: prehistory, context and summary, Oxbow Books, Oxford

Evans, C, Edmonds, M, Boreham, S, Evans, J, Jones, G, Knight, M and Legge, T 2006. "'Total archaeology" and model landscapes: excavation of the Great Wilbraham causewayed enclosure, Cambridgeshire, I975-76', Proc Prehist Soc, 72, I I3-62

Evans, J G I97I. 'Notes on the environment of early farming communities in Britain', in Simpson I97I, I I-26

Evans, J G, Limbrey, $\mathrm{S}$ and Cleere, $\mathrm{H}$ (eds) 1975. The Effect of Man on the Landscape: the Highland Zone, Council for British Archaeology, London

Field, D 2005. 'Some observations on perception, consolidation and change in a land of stones', 
in G Brown, D Field and D McOmish (eds), The Avebury Landscape: aspects of the field archaeology of the Marlborough Downs, 87-94, Oxbow Books, Oxford

Fowler, P J 1971. 'Early prehistoric agriculture in Western Europe: some archaeological evidence', in Simpson 1971, I53-83

Fowler, P J I978. 'Lowland landscapes: culture, time, and personality', in S Limbrey and J G Evans (eds), The Effect of Man on the Landscape: the Lowland Zone, I-I2, Council for British Archaeology, London

Gillings, M and Pollard, J 1999. 'Non-portable stone artefacts and contexts of meaning: the tale of Grey Wether (www.museums.ncl.ac. uk/Avebury/stone4.htm)', World Archaeol, 3I, I79-93

Gillings, M and Pollard, J 2004. Avebury, Gerald Duckworth and Co Ltd, London

Gillings, $M$ and Pollard, J 20r6a. 'Making megaliths: shifting and unstable stones in the Neolithic of the Avebury landscape', Cambridge Archaeol F, 26, I-23

Gillings, $M$ and Pollard, J (eds) 20I6b. Landscape Archaeology: critical concepts in archaeology, Routledge, London

Gillings, M, Pollard, J, Wheatley, D and Peterson, $\mathrm{R}$ 2008. Landscape of the Megaliths: excavation and fieldwork on the Avebury monuments, 1997-2003, Oxbow Books, Oxford

Goddard, H E and Bouverie, E O P I908. 'The fifty-fifth general meeting of the Wiltshire Archaeological and Natural History Society', Wiltshire Mag, 35, 529-33

Harmansah, O (ed) 20I4. Of Rocks and Water: towards an archaeology of place, Oxbow Books, Oxford

Holley, R 20I0. 'Crowdsourcing: how and why should libraries do it?', D-LIB: Mag Dig Lib Res, 16 (3/4), <http://dlib.org/dlib/marchı/ holley/ozholley.html> (accessed I8 May 2020)

Hoskins, W G 1955. The Making of the English Landscape, Hodder and Stoughton, London

Johnson, M 2007. Ideas of Landscape, Blackwell, Oxford

Leicestershire County Council 2009. Report on the Completion of the Community Heritage Initiative and its Legacy, Leicestershire County Council, Leicester

Limbrey, S and Evans, J G (eds) 1978. The Effect of Man on the Landscape: the Lowland Zone, Council for British Archaeology, London

Mantell, G I833. The Geology of the South-East of England, Longman, Rees, Orme, Brown, Green and Longman, London
Nash, D J and McLaren, S J (eds) 2007. Geochemical Sediments and Landscape, Blackwell, Oxford

Pollard, J and Gillings, M 2009. 'The world of the Grey Wethers', in B O'Connor, G Cooney and J Chapman (eds), Materialitas: working stone, carving identity, Prehist Soc Res Paper 3, 29-4I, Oxbow Books, Oxford

Pollard, J and Gillings, M 20I0. 'Sarsen stories', in H Lewis and S Semple (eds), Perspectives in Landscape Archaeology: Papers presented at Oxford 2003-5, BAR Brit Ser 2I03, 7-II, Oxbow, Oxford

Prestwich, J 1854. 'On the structure of the strata between the London clay and the chalk in the London and Hampshire tertiary systems. Part II: the Woolwich and Reading series', $Q \mathcal{F}$ Geol Soc, Io, $75-138$

Pryor, F 1978. Excavation at Fengate, Peterborough, England: the second report, Royal Ontario Museum, Ontario

Rahtz, P A (ed) i974. Rescue Archaeology, Penguin, Harmondsworth

RCHME 1960. A Matter of Time: an archaeological survey of the river gravels of England prepared by the Royal Commission on Historical Monuments (England), HMSO, London

RCHME I970. An Inventory of the Historic Monuments in Dorset. Vol 2: south-east, Roy Comm Hist Monuments Engl Inv, HMSO, London

RCHME 1993. Recording England's Past: a review of national and local sites and monuments records in England, HMSO, London

Richards, C 20I3. 'Interpreting stone circles', in C Richards (ed), Building the Great Stone Circles of the North, 2-30, Windgather Press, Oxford

Rupert Jones, T i886. 'History of the sarsens', Wiltshire Archaeol Natur Hist Mag, 23, I22-54

Simpson, D D A (ed) 1971. Economy and Settlement in Neolithic and Early Bronze Age Britain and Europe, Leicester University Press, Leicester

Small, R J, Clark, M J and Lewin, J I970. 'The periglacial rock-stream at Clatford Bottom, Marlborough Downs, Wiltshire', Proc Geol Assoc, 8I, 87-98

Smith, A C 1884. Guide to the British and Roman Antiquities of the North Wiltshire Downs, The Marlborough College Natural History Society, Marlborough

Summerfield, M A and Goudie, A S r980. 'The sarsens of southern England: their 
palaeoenvironmental interpretation with reference to other silcretes', in D K C Jones (ed), The Shaping of Southern England, Inst Brit Geog Special Pub II, 7I-IOO, Academic Press, London

Taylor, C 1974. Fieldwork in Medieval Archaeology, Batsford, London

Taylor, C I983. Village and Farmstead: a history of rural settlement in England, George Philip, London

Taylor, C 20I0. 'Founders: Collin Bowen', Landscapes, II, 84-94

The Times, II Nov 20I I, 'Collin Bowen', 66

Thomas, J 20I2. 'Archaeologies of place and landscape', in I Hodder (ed), Archaeological Theory Today, 2nd edn, II5-3I, Polity Press, Cambridge

Ullyott, J S and Nash, D J 20I6. 'Distinguishing pedogenic and non-pedogenic silcretes in the landscape and geological record', Proc Geol Assoc, 127, 3I I-I9
Ullyott, J S, Nash, D J, Whiteman, C A and Mortimore, R N 2004. 'Distribution, petrology and mode of development of silcretes (sarsens and puddingstones) on the eastern South Downs, UK', Earth Surf Proc Landforms, 29, 1509-39

Watkins, A 1925. The Old Straight Track, I974 edn, Abacus, Sphere Books Ltd, London

Whitaker, K A 2020a. 'Sarsen Stones in Wessex project: Data transcription strategy, methodology and protocols', Humanities Commons CORE, <http://dx.doi.org/ı. I76I3/c2x9-d837> (accessed I8 May 2020)

Whitaker, KA 2020b. 'Sarsen Stones in Wessex project survey archive report', Humanities Commons CORE, <http://dx.doi.org/IO. I76I3/fvnh-xcI5> (accessed I8 May 2020)

Whitaker, K A 2020c. 'Sarsen Stones in Wessex', University of Reading. Dataset, $<$ http://dx.doi.org/IO.I 7864/I947.249> (accessed I June 2020) 